\title{
The Importance of Stakeholder Involvement in Strategic Development of Destination Management: The Case of the Mirna Valley Destination
}

\author{
Maja Žibert \\ University of Maribor, Faculty of Tourism, Slovenia \\ maja.zibert@student.um.si \\ Marko Koščak \\ University of Maribor, Faculty of Tourism, Slovenia \\ marko.koscak@um.si \\ Boris Prevolšek \\ University of Maribor, Faculty of Tourism, Slovenia \\ boris.prevolsek@um.si
}

The aim of this paper is to explain further the importance of stakeholder involvement in strategic development of destination management with the purpose of getting a deeper understanding of what different stakeholders perceive as more or less important when it comes to destination management. Key concepts of strategic and destination management are explained in the theoretical part. Based on this, we have posed ourselves the main research question: What are the desires of different stakeholders in the development of the destination in the light of strategic management? Explanations and viewpoints of other authors were summarized, and attempts were made to derive new viewpoints based on our research questions. Results confirm the findings that the life of the local population should be included and engaged actively in the development, when developing the destination and identifying the potentials. Each group of stakeholders plays a special role in the development of the destination. This paper offers an overview of the analysis challenges and trends in the development of a small tourist destination. The most reasonable and appropriate for small destinations is to undertake the management of 'bottom-up' and to consider a common brand, which will provide recognition of the place and its key tourism products.

Keywords: strategic management, destination management, stakeholders, development of destination

https://doi.org/10.26493/2335-4194.10.43-55

\section{Introduction}

When a destination wants to be classified as a tourist destination, it should provide many activities that tourists identify as a 'tourist' experience (Bornhorst, Ritchie, \& Sheehan, 2010). Concerning their development, the destinations defined challenges and identi- fied trends according to which they assumed a transparent image. The trends form a group of good examples and practices that tourist destinations experience throughout their development. Ovsenik (2003) points out that it is important for the environment to identify itself with the industry in the shortest possible time 
if they adopted a decision about destination management according to the principles of destination management.

Morgan, Pritchard, and Piggott (2003) have, through their research, confirmed that, while the provision of direction for development is implicit in visioning, what is important is the emphasis on formulating the destination vision through a publicly-driven process based on stakeholder values and consensus, rather than through a more private expert-driven process based solely on market forces. The same authors further stress that stakeholders must agree that the final vision statement provides both a meaningful and an operational dream for the future of their destination - one that reflects the values of destination stakeholders while not ignoring the realities and constraints of the marketplace.

When conducting research about stakeholder involvement into strategic development of a destination Aas, Ladkin, and Fletcher (2005) identified that indepth interviewees were the best way to understand the importance of this involvement, since they gave them what they called 'a wealth of information on the stakeholder project and the development of tourism.'

In Australia, a research has been conducted to find out to what extent the strategic planning supports real planning in tourism. Ruhanen (2010) conducted 31 structured interviews with the representatives of five tourist destinations. She came to the conclusion that planning in tourism is focused on short terms and immediate effect, while real strategies are lacking. She also emphasizes that the policy of sustainable development has the appearance of some kind of movement, nevertheless, the concern about the financial effect is still predominant.

New destinations in formation can, thus, follow those examples and conspicuous trends in their development. The Mirna Valley is a geographic entity within the broader Dolenjska tourism destination. It is located on the territory that used to be part of the Municipality of Trebnje; today, it consists of the Municipalities Mokronog-Trebelno, Mirna and Šentrupert. It forms part of central Slovenia, particularly the South-Eastern part of central Slovenia, bordered by the nearby Municipalities: Ivančna Gorica, Šmartno pri Litiji, Litija, Sevnica, Škocjan, Šmarješke Toplice, Novo mesto, Mirna Peč and Žužemberk.

While going into this research, our presumption was that the development of the region and tourism proceeds as anticipated, and in line with the development strategy conceived by the documented Strategic Action Plan for establishment of the tourist destination Mirna Valley. This action plan does not discuss the meaning of the strategic management. Through this article, we will discuss the importance of the strategic management and the inclusion of various stakeholders from the public, civil and private sectors. It would, thus, be more than welcome if they associated and cooperated in the development. During the research we wanted to verify how the individual sectors perceive and experience the development of tourism and environment in the Mirna Valley area.

\section{Theoretical Background}

\section{Cooperation of Stakeholders}

in Strategic Management

In their work, Haugland, Ness, Grønseth, and Aarstad (2011) state clearly that research on destination development is very fragmented, since some studies focus primarily on one or a few selected areas of destination development, thus paying limited attention to multilevel issues and theoretical integration, while, on the other hand, there are studies that take a more holistic, phenomena-driven view, making theoretical delimitation difficult. With the importance of continuous development, it is also very hard to determine when destination development ends and destination management begins.

Based on the views of many other authors, it was Haugland et al. (2011) who claim that tourism destinations can be considered as complex networks that involve a large number of co-producing actors delivering a variety of products and services. This complexity mentioned by the authors can be seen as something that clearly differentiates destination development and destination management from organizational development and organizational management.

As is pointed out by Dimovski and Panger (2008), the strategic management is often considered to equal executive management. Brownman (1994), claims that 
the key feature of the strategic management is taking decisions continuously, influencing the effect of organization and implementation in practice. Belak (2002), says that the basic duty of the strategic management is searching for, creating and controlling the strategic potentials of the organization. On the other hand, Uran (2006), views the role of the strategic management as dealing with the understanding of the nature of competitive advantage and the manner of how to create and retain that advantage over the others. In the opinion of Tavčar (2008), long-term and comprehensive control of the organization, focused on the important matters, is in question. Tavčar (2002) said: 'The assumption that the conditions from the past will continue in the future, has become less and less probable.' In that way, she defines one of the key reasons for the appearance of long-term and, later on, strategic planning.

In their paper, Mackey and Zundel (2016), show that worldwide, many classifications of the Strategic Business Management Schools are known, such as McKiernan, Mintzberg, and Whittington (Whittington, 2001), divide the Strategic Business Management Schools as follows: Conventional, process, evolutionary and system schools.

The conventional school advocates the attitude that the strategy can be developed on the basis of rational system process, while the model of strategy forming should be simple and as little formalized as possible. The process school starts from the assumption that differences occur between the planned and realized strategy, while, during the implementation process, the in-process strategy still appears. The evolutionary school denies that the business managers are qualified enough to form strategy. That implies that the profit maximization is governed by the market and not strategy. The system and the conventional schools advocate the capacity of organizations to plan and act effectively inside their environment (Pučko, Čater, \& Rejc Buhovac, 2009).

\section{Strategic Management in Tourism}

Understanding historical and modern trends and movements in the business environment is the basic prerequisite for strategic planning in tourism. New ini- tiatives for such planning will require from successful planners to have the capacity to predict new key movements and developments. That will lead to creating innovative and effective strategies. In the area of tourism, the relation between bidders and the market/business environment is unique, since the latter embraces the entire world. The tool PEST is one of the most convenient tools for the analysis of the business/market environment. That analysis governs the survey of political, economic, social and technical factors. Because of the unique and specific business environment, characteristic of tourism, Mountinho, Ballantyne, and Rate (2011) propose another model of analysis of the business environment. That is the tool SCEPTICAL. S - Social factors, C - Cultural factors, E - Economic factors, P - Physical factors, T - Technical factors, I - International factors, $\mathrm{C}$ - Communications and infrastructure factors, A - Administrative and institutional factors and $\mathrm{L}$ - Legal and political factors (Mountinho et al., 2011).

In Jordan, strategic planning is exploited by the use of various techniques. In his research, Aldehayyat (2011), investigates the importance of strategic thinking in tourism in Jordan. One of the principal findings was that this was done only by the people, stakeholders and creators of the destinations, and that outside consultants were not hired.

Nevertheless, Guiver and Stanford (2014), have found that a Destination Manager seldom applies the concept of strategic judgement of influences. In their research into countryside destinations in Great Britain, these authors have concluded that successful introduction of integrated planning is prevented by the structure of the tourist industry, public financing, and difficulties in coordination of several agencies having equal goals.

Okumus and Wong (2005), have found that strategic management incorporated different views and models, implying great variety in concepts from the point of view of teaching. The two authors recapitulate that modern curricula should focus on the implementation of strategies, RBV (Resource-Based View) management of know-how, establishing new companies, learning organization, managing a non-profit organization and multi-national company. 
Strategic management should aim at maintaining of the tourist destination and the long-term stable position competitively, while strategic marketing should promote combining the tasks of the tourist destination management and its perception in the eyes of the tourists.

\section{Destination Management}

The basic definition of management and/or planning refers to organizing, managing and control. The same competences are also attributed to the destination management concerning the tourist offer, but it Is also necessary to add the marketing and communication component as a key to achieve transparency, and, consequently, economic and development success of the destination (Magaš, 2003).

Laesser and Beritelli (2013) see destination management (DMO) as the management process that aims to attract visitors and allocate time and money in a specific geographic space. As they said, destination management should comprise different domains of activity, such as planning, lobbying (on behalf of all stakeholders), marketing in a comprehensive way, and coordinating a seamless customer experience. As $\mathrm{Mu}-$ nar (2012) pointed out, D MOs have several main functions.

Firstly, the coordination of marketing strategies, including the destination brand, and the management of information and knowledge about the tourism destination; secondly, the establishment of networks and initiatives to improve the destination offer, and thirdly, the coordination of tourism planning and development. The D mo should lead and co-ordinate this different aspect of destination, as is shown below.

In Figure 1, we can see the proposed scheme of the DMOs activities and organization as seen by United Nations World Tourism Organization (2007). On the top part, we see the possibilities that the destination provides, and on the bottom part we see the issues around which DMOs have to work in order to take full advantage of what a destination has to offer to potential visitors.

Tourism is nowadays a sector in a state of transition. Therefore, the traditional role of D MO is changing. As Presenza, Sheehan, and Ritchie (2005) pointed

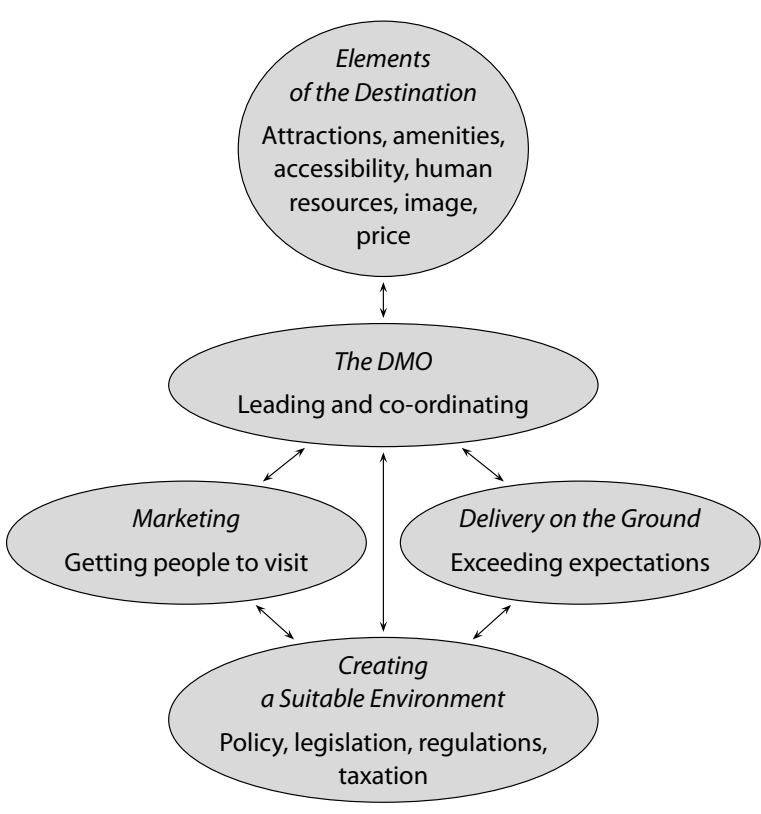

Figure 1 Destination Management (DMO) (adapted from United Nations World Tourism Organization, 2007)

out: 'DMOs are becoming more prominent as "destination developers" by acting as catalysts and facilitators for the realization of tourism developments.'

\section{Stakeholders at the Destination}

The connection point inside all three groups of stakeholders (private, civil and public sectors) at a destination is the destination management. It is coordinating all interests and encouraging a consistent and sustainable development, plus its marketing. Within the destination, each of the stakeholders has his interests, wishes, expectations and favors. Ackermann and Eden (2011), said that one stakeholder's actions can generate a dynamic of responses across a range of others. Relations between stakeholders at a destination are formal and informal.

Tourism organization runs on several levels, and among them are related tasks. It is necessary to define clearly the tasks and scope of the work of each stakeholder. Uran (2014) prepared a structure, which shows us the relationship between the private and public sectors and civil society on the one hand, and the rela- 


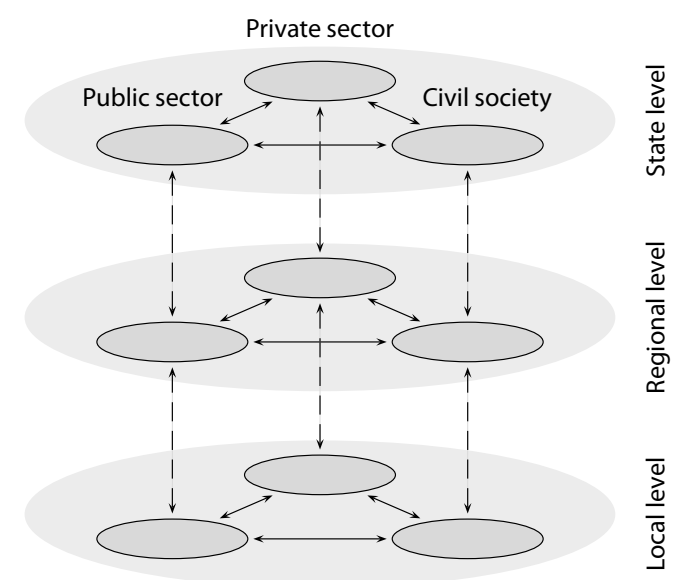

Figure 2 Stakeholders (adapted from Uran, 2014)

tionship between them at country, regional and local levels. This level of organization of tourism can also be found within the destination of the Mirna Valley.

In this way, we can see that the stakeholders from the private sector are oriented to the features of the destination in the short and long-term. They are interested primarily in the promotion and growth of the destination on the common tourist market. The public sector is concerned about the social and economic interests in the long-term and puts much emphasis on the destination development. The civil society expects primarily the improvement of life quality within the destination with personal engagement. Adequate development of the destination and successful functioning of the system within the destination requires cooperation of the key three sectors of stakeholders, and well qualified strategic managers and managers active at the destination itself. Sautter and Leisen (1999) said that for tourism planners it is important to consider the interests or perspectives of the different stakeholder groups.

According to Wall and Mathieson (2006), 'Stakeholder perceptions are accepted as crucial for evaluating participatory processes and devising effective strategies for implementing sustainable tourism, but there is no clear understanding of how best to increase the involvement of stakeholders in sustainable tourism. The importance of stakeholder involvement in strategic development of destination man- agement was classified in a research paper about a multi-stakeholder involvement management framework. Waligo, Clarke, and Hawkins (2013) explained that the inclusion of stakeholders affects development and establishment of sustainable tourism. The argument was based on 3 assumptions. First, stakeholders represent a core component of the implementation of sustainable tourism (stakeholder identification), second, stakeholder perceptions are sought to facilitate the development of effective stakeholder involvement strategies (stakeholder engagement), and third 'stakeholder involvement' can facilitate the achievement of sustainable tourism objectives (multi-stakeholder involvement).

Based on a theoretical overview, we can confirm the fact that the life of the local population should be included and engaged actively in the development when developing the destination and identifying the potentials. A tourist destination changes in the course of time in accordance with changes in all the environments forming it. Through the view of Magaš (1997), who talked about the destination cycles, we could conclude that Mirna Valley is in the development phase. That time the destination management becomes a necessity, as the complete offer must be integrated into the environment.

At present, it is still too early to speak about the consolidation phase, but an important question is what is desired after that phase, either an autonomous way or development of the tourist offer within a wider destination? It is well-known that problems, ranging from social, ecological to economic, start to appear at the destination. Such difficulties are faced even sooner, if the destination is too little for singular development and organization in terms of human capacities and environmental offer. Therefore, it is an appropriate moment now to ask the question how to go on. The answer is by organizing efficient destination management; however, the first thing is to define clearly the tasks and scope of work of each stakeholder, and then start to coordinate all aspects by stakeholders. However, the positive effects of destination development are caused by (1) Exchange of information, (2) Use of synergies and (3) Coordination of action (Volgger and Pechlaner, 2014). 


\section{Methodology}

Preparation of the research contents was based on the document Strategic Action Plan for establishment of the Mirna Valley destination (Koščak, 2013), and on the study of implementation concerning individual priorities between the stakeholders at the destination. The Strategic Action Plan for establishment of Mirna Valley destination is a document that was presented to the stakeholders in tourism in the Mirna Valley area, and presents ideas about how to establish Mirna Valley as a destination.

Based on the theoretical overview and the knowledge of the Strategic Action Plan for establishment of the Mirna Valley destination, we have created the following research questions:

1. What are the current challenges in destination management of Mirna Valley?

2. How can we get the key stakeholders (i.e. civil society, private sector, public sector) to be involved more actively in the destination management of Mirna Valley?

3. What are the expected future trends in destination management of Mirna Valley?

On the basis of the examination of the Strategic Action Plan for establishment of the Mirna Valley location as a tourist destination, and after identifying individual priorities stated therein, a questionnaire has been prepared. In that way, the implementation of priorities and the destination development were verified. The questionnaire was prepared in conjunction with the purpose of the research work to find answers to the research questions.

\section{Representation of the Research Sample}

In total, we have conducted 14 interviews with representatives in all sectors and in each Municipality separately, receiving a wider insight into the situation in the field. The Tourist destination of the Mirna valley consists of 3 Municipalities. We interviewed all three representatives of local self-government - Mayors in this part the sample are equal to the entire population. In the private and civil sectors were interviewed key players in each. In the civil sector, these are institutions which cover most of the organized public events. With the interviews, we cover only the part of the private sector which is linked to tourism services, and they recorded the highest number of visitors. It is also important to note that the Land of hay-racks was interviewed - a representative of the largest tourist service provider in the Mirna Valley. In this part, the population represents 20 individuals, and the sample we have gathered contained 11 of them. The aforementioned 14 in-depth interviews were made in the field in June, 2015 and July, 2015.

In the Mirna Municipality those were the Mayor and a member of the Municipal Administration, the President and some members of the Sports Society Partizan, and the 'Aladin' adventure ranch head. In the Šentrupert Municipality the Mayor, the President and some members of the Ethnic Society Draga and the guesthouse workers from the Winehouse Frelih and the Land of hay-racks were interviewed, while in the area of the Mokronog-Trebelno Municipality, we talked with the Mayor, a member of the Municipal Administration, the President and some members of the Tourist Society and workers of the Guesthouse Deu.

The result of the research shows that 14 participants in the selected sample comply with the preparation target of the work contents. In the field, we contacted the key persons in the Mirna Valley destination organization. We were interested in the key targets of priorities formed by their creators. We selected the persons at executive level in the individual area of the development and promotion of tourism at the Mirna Valley destination. In our opinion, they were able to present in detail the actual state of the destination management development and organization, preparation of various touristic and cultural events.

Based on the recording of statistics of tourist arrivals, we divided them into 2 groups. First 'the small group' and another 'the biggest group'. From each of the groups we took 5 interviewees, the 11th was the Land of hay-racks - a representative of the largest tourist service provider in the Mirna Valley.

We were interested in the key targets of priorities formed by their creators, when conceiving the development strategy of the Mirna Valley destination; we were also keen to know what concrete activities had already been carried out by them as members of the 
individual sector to make the priority live, and what, in their opinion, the indicators controlling the implementation and functioning of priorities at the destination were. Below, the basic questions asked in the interviews and the principal research findings are presented.

We contacted the interviewees personally and recorded their answers on the spot according to the key items. By means of a computer, the transcripts were analyzed and the principal findings written in sets as follow: Public sector, private sector, civil sector.

Afterwards, interviews were interpreted sector by sector, first individually, then by making a swo T analysis of findings. The interviewees took part in interviews voluntarily. Interviews were, therefore, agreed upon in advance.

\section{Research Methods}

The interview consisted of two parts. The first part comprised 4 sets, each set having three questions. The sets covered priorities given by authors of the document Strategic Action Plan for establishment of the Mirna Valley destination as development orientations and vision for managing the future development of sustainable tourism in the Mirna Valley destination. Priorities, on which the questions asked from the interviewees were based, had been devised on the basis and principles of participative planning, the representatives of public, private and civil sectors having the possibility of giving operational proposals at the time of preparation of the Strategic Action Plan for forming the vision and for future action.

In the main part, the interviewees were asked what, in their opinion, the key targets of those priorities are, what concrete activities had already been performed by them as individual sector to bring priority into life and what, in their opinion, the indicators controlling the execution and functioning of priorities at the destination are.

In addition to the substantive part, also the basic demographic questions were asked (age, education, profession).

With the help of field research, we verified the implementation of the development strategy in the Mirna Valley region, so that we would be able to as- certain that the area develops in the desired way, and at the rate directed by the development strategy.

\section{Data Interpretation and Analysis}

\section{Public Sector}

After the interviews, we set out to analyze the answers we have received from the interviewees within the public sector. The most important thing for the public sector is to activate internal potentials and to include the local community. It is important that the destination should be managed and formed on the principle 'bottom-up', i.e., the locals should see potential behind it, while the public sector tries to manage it with responsible leadership. One of the Interviewees said clearly: 'Sometimes it is felt that some people lack the sense of community and would like to fly solo.' They have a common opinion, capable management linking together the entire destination is needed, especially now, the destination has been established, an important step will be its managing.

They are convinced an important area is also the cultural heritage, but they said the State, nevertheless, follows the traced path. 'It is important to recognize the development-vision steps; the vision is carried on and, in that way, the desired management, i.e., the management "bottom-up" is reached, said one of the Interviewees. They said it is hard to speak about the operational phase of the project, as the project has been stopped because of financing, but they all want a common brand name, which is also one of their joint goals. In the project of Mirna Valley destination establishment they must appear on the scene homogeneously. The document - Strategy of establishment of Mirna Valley tourist destination - could be viewed from a wider standpoint and seen also in the light of economy.

They said it is well-known that the prospects of the $\mathrm{EU}$, today, are centered in tourism. Therefore, they are confident that they are turning in the right direction; regrettably, wider associating among them is missing. 'We must be aware that the destination is attractive to tourists, therefore, statistics' researches are needed to be able to design tourist packages which, so far, have been missing, said one of the interviewees. At present, only the Land of hay-racks has such packages 
Table 1 Main Questions

1. What, in your opinion, is the key target of this priority?

2. What have you already done (in the framework of planned activities) to make priority live - what activities have been executed since preparation of the document till now?

3. What, in your opinion, are the indicators of priority functioning control?

as a tourist product of the Mirna Valley destination. They also mentioned that sustainable development should not be neglected. 'That is the preferred topic of tourism development in the entire EU. Experiences in nature and the rich heritage must be our priorities.'

\section{Civil Sector}

Their activities link together the people and inhabitants beyond the borders of the Municipality. They are also active in tourism, particularly in organization of events. They feel that the Municipalities, so far, have not yet managed to agree on joint management of the destination, as would be desirable. In that way, they would know when various projects and events take place within all societies; 'maybe the system financing would be organized better' said one of the Interviewees.

Their activities include publishing of folding booklets; they are active in cultural activities, in organizing various events, including events for tourists. In addition, they also receive funds from membership fees, donations and sponsorship. They admit that in the sphere of protection and preservation of cultural and natural heritage a lot more could be done. 'Tourism is sold by good stories. Will we win them by preserving natural and cultural heritage? Something more is needed,' was the convinction of an Interviewee. 'Our management must know precisely what it wants and conduct a common policy. The management must proceed step by step, not in a hurry', said someone else. In their opinion, management could be better and they are concerned how a function, linking together the Mirna Valley area, could operate. They are asking if they have to act together and conduct a common policy, or would they then branch away and be an autonomous destination within the Dolenjska region. They are sure that the idea of a common brand name is an excellent idea. They are sure that the destination also needs indicators of control, telling them whether they are going in the right direction.

\section{Private Sector}

By system and transparent destination management in the private sector its members are eager to see the result, i.e., an increased number of tourists at the destination. From their point of view, the result of all priorities would be an increase in profit. They belong to a group that offers special tourist services at particular destination micro locations, and without them, the destination could not be imagined such as it is. 'An important component here is the private sector of stakeholders in the destination,' they are convinced. They said the private sector drew attention to the Choice in the Land of hay-racks emphasizing that they must work hard on their promotion and deliberate according to their best appearance on the promotion market, since the image in the right market groups of consumers is important. 'Protection and sustainable development of cultural and natural heritage are today, of course, of great importance, as the sustainability priority', they pointed out again and again. A lot has been done on that priority, in comparison with the past. In their opinion, they must continue working on that priority at an accelerated rate and more concretely. As they pointed out, for them it is the market activity that counts the most. What seems for them most important at the destination is the coordination of individual representatives within the public sector, since, from there onwards, the destination is managed. 'The connecting link is missing,' they also said.

\section{SWOT Analysis of the Mirna Valley}

By the comparative research method, we compared the interviews from individual sectors and tried to find mutual links, common points and/or differences; at the end of the research, by use of the synthesis method, 
Table 2 swот Analysis

Strengths

- Favorable geographic position (airports Ljubljana, Zagreb, Xth motorway corridor, proximity of frontier, proximity of principal EU markets)

- Attractive landscape (natural, cultural heritage) for residence and tourism

- Natural resources (forests, waters, ...)

- The Mirna Valley area is an example of active tourism

- Rich cultural heritage of countryside

- Local organization: Established and active structures

- Hospitality and friendliness of locals

- Opportunities for free and safe walking

- Experience in acquiring EU funds
Weaknesses

- Increase in the percentage of jobless young people

- Lack of green fields

- Weak cooperation culture and skills

- Poor offer for high-rank guests wanting to spend more money (Russians)

- Lack of tourist programs and new interesting and innovative products in spite of potentials offered by the region

- Deficient statistics' research; lack of public sanitary conveniences, parking lots, scarce and inappropriate multi-purpose facilities for tourism, illicit dumping sites

- Low transfer of know-how, tradition and skills to younger generations and familiarization of the young with the importance of tradition

\section{Threats}

Opportunities
- Accessibility and good quality of environment (factor attracting creative people and investments)

- Associating of sectors (technological development - tourism - farming - education)

- Growth of individual tourism in the area

- Relaxation and anti-stress programs as a type of offer of integral tourist products

- Chances for development of green tourism

- The area features intact and preserved nature offering potential for tourism and quality of life itself

- Protected and naturally preserved areas may be visited by tourists and visitors
- (Too) slow responding (indecision), and low readiness to take risks

- Lack of developing - managing know-how and regional Project Managers

- Deepening of social inequality

- Lack of development cooperation within various development strategies and proposals for joint area management

- Unfavorable circumstances for investments, particularly, because of excessively expensive loans

- Changes in the labor market - the increasing number of jobless people in the farming sector

- Keeping of statistics - decrease in overnight accommodations, good and ready integral tourist products we tried to link theoretic knowledge and explanations with practical facts, gained thanks to interviews. The swot analysis of the Mirna Valley area is presented below. Thus, some strengths, as well as weaknesses, opportunities and threats, apply also to wider Dolenjska, and not only to the Mirna Valley. Table 2 presents strengths according to the swo T analysis.

The Strategic Action Plan for establishment of the Mirna Valley destination (Koščak, 2013) proposed several steps in establishing the Mirna Valley destination, and one of the very important tasks was to determine priorities on the basis of swот analysis and to determine actions, how to realize them. In the following part, we are presenting the priorities and certain ideas about what actions to take.

\section{Priority 1: Promoting Business Growth for Jobs and Economic Growth for a More Developed Area}

In comparison with Slovenia, the Mirna Valley area is marked by low added value below average, low GNP 
and lower salaries. The Mirna Valley area also features bad transfer of know-how, tradition and skills to young generations, bad familiarization of the young with the importance of tradition, deficient keeping of statistics, lack of public sanitary conveniences, parking lots, rare and inadequate multi-purpose facilities, some illicit dumping sites can be found.

Actions:

1. Continuous learning, innovation and the adoption of the necessary knowledge.

2. Prepare an attractive environment for the development of the company.

3. Pay attention to the surrounding tradition and handicrafts.

\section{Priority 2: Farming Friendly to the Environment and the Development of Additional Activities on the Farm}

Tourism at the destination of the Mirna Valley must be connected to agriculture. The area of the Mirna valley is predominantly rural. We have to maintain farming and forestry. For these activities, for their further development, we should promote the use of new technologies. We need to create conditions for further conservation of the countryside. Also, we should increase and exploit better the potential of tourism in the spa, wellness, business, recreation, winter, and event areas, etc.

Actions:

1. On farms to introduce additional activities (sleep in the hayloft).

2. The increase in production and quality of products on the farm (certification).

3. Execution of practical learning through educational programs.

4. The increase in sales of agricultural products and foodstuffs.

5. Local farmers supply the local population with their food.

\section{Priority 3: Tourism and Infrastructure}

Dolenjska region has the longest number of nights of domestic guests. For overnight stays by foreign guests they were overtaken by a number of other Slovenian regions. It would be necessary to establish a linkage between heritage and tourism. It is necessary to accept the changes and trends of globalization. It is necessary to be on the visibility of the area, it is necessary to draw a good competitive bid to restore the natural and cultural heritage and to develop sustainable tourism. A crucial key to success in tourism is the individual approach to guests. We can offer relaxation in thermal water, learning about the natural and cultural heritage, and traditional cuisine and wines.

Actions:

1. Better infrastructure for access and indications to the facilities, attractions, heritage.

2. Larger and more varied tourist offer and services.

3. Improve the organization of cooperation between all providers in the Dolenjska region.

4. Young people present interest in tourism.

\section{Main Findings}

A tourist destination changes in the course of time in accordance with changes in all the environments forming it. At the beginning the destination is, usually, still some kind of intact nature and not yet infested with tourism. Here, the destination still has many chances of being integrated into the life of the local population in the course of development. Engagement implies that much effort is applied to the development of the destination. At this stage, authors Jamal and Getz (1995) said that tourism development takes on the characteristics of a public and social good. The result is the increase of the number of tourists, enhancement of the offer, building of tourist infrastructure etc. The so-called tourist seasons are formed, and also many 'tourist' benefits could be shared by numerous stakeholders at the destination.

Later on, the destination management becomes a necessity, as the complete offer must be integrated into the environment. It may happen that the tourist destination stagnates. This is the time when the destination is no more as attractive than before. Thus, a change of offer is necessary to retain the guests or to attract them anew. Slowly, the destination starts to face social, ecological, economic and other problems. Dur- 
ing the decline, the destination usually loses its value. In the tourist destination the management is changed, the accommodating capacities get lost. In this phase, the programs must necessarily be redefined, products renewed and modified, in short, the system must be established anew if the destination is to revive again. This is the step of some kind of destination reveal. In each stage of development, stakeholders perform a special task.

All sectors of stakeholders mentioned the importance of a common brand; therefore, developers should take into consideration the need to design a common brand. It was also stated by Blain, Levy, and Ritchie (2005) that: 'destination logos can facilitate many D MO marketing activities to establish brand image and identity, particularly relevant before the actual visitor experience.'

Involvement of stakeholders in strategic management of a destination is important in each stage of development. The article shows the importance of cooperation of key stakeholders (i.e. civil society, private sector, public sector) at different levels. Moreover, the article demonstrates the importance of the 'bottom-up' development in a destination, which we can frequently interpret as a pressure on public institutions and the public sector, for example: For additional building of infrastructure. Reid (1996), mentions two approaches to the process of achieving the goals of destination development. In the model of 'bottom-up' approach there is present decentralization of authorities at a lower level. Local authorities have an important role in the local ecosystem management and development activities - also in terms of tourism organizations and other activities (for example, arranging local transport infrastructure organization). The top down' approach is the opposite, in implementing the principles of tourism development; the country plays a major role.

In the area of the Mirna Valley a joint managing policy must be found, representatives of individual destination sectors must be more incorporated into its management and, at the same time, the financing arrangements intended for the development should be examined concretely and thoroughly. To solve the problem of non-constructive destination, better run- ning of the management would have to be established. A Destination Manager is needed, considered to act as the principal driving wheel in the region. For the time being, in this relatively small area of Slovenia within the Dolenjska destination, a common development policy and appearance on the market have not yet been introduced.

Through interviews we could conclude that the Mirna Valley destination management is led to a large extent by the development center Novo mesto. An independent management center in the Mirna Valley area within the Dolenjska tourist destination had not yet been established, though the vision and strategy anticipated its establishment within one year after publishing the document. With a common interest in the development and destination marketing of the Mirna Valley, including all three municipalities, the Mirna valley can be developed as an important tourist destination. The number of visitors is increasing every year at the destination of the Mirna Valley. This is evidenced by the statistical recording by a representative of the largest tourist service provider in the Mirna Valley - the Land of hay-racks. Only with destination management, with new lodgings capacity and some other parts of the tourist infrastructure, will it become a strong and distinctive sightseeing attraction.

\section{Limitations and Suggestions for Future Research}

Every research has some limitations. In this case, we can talk about the limitation about the size of the research population, to minimize its effect we have conducted interviews with all Mayors within the destination and selected carefully a sample of 20 most important tourist providers at the destination; we managed to capture the opinions of 11 of them. For future research, it would be proper to use another research method - for example, a survey which would cover a larger number of respondents.

It would be proper to think about a common brand name in the wider destination but, today, we do not have any concrete concepts of it. In the Mirna Valley area, also the cultural and natural landscape changes. With the change of generations many vineyards are abandoned in the valleys, especially in comparison with the past, and there are more quarries in some way 
spoiling landscape. When thinking about the future, we must ask ourselves what impact will a new road link between North and South (known as the 3rd development axis) have on us when it is constructed? Not only in the sphere of tourism, but also in the spheres of economy and transit. The Tourist Information Center should not be a building or organization only. There must be informers, who will be capable of providing useful information to tourists on the premises, in the flower shop, or in the street. Let us not forget that we are living in the age of advanced technology, when smartphones play an important role. Applications on the phones (about the offer of Mirna Valley and its contents too) should become one of the priorities to be established. Our work is an appropriate starting point for further researches in the Mirna Valley destination, particularly from the point of view of sustainable tourism, since, according to modern trends the sustainability and development of the destination must go hand in hand.

\section{Conclusions}

The starting point of any strategic tourism policy is a tourist destination (city, region, country) as a group of interconnected stakeholders. The activity of each individual affects the activity of the others. Certain common objectives must be defined and achieved in a coordinated way. The public sector should be responsible for the future development of the destination (development plans). The tasks of the public sector are interest rate subsidies, employment assistance, infrastructure in the Municipality, taking care of monuments, organization of events and market research.

The private sector of the Mirna Valley is well represented. The leading group at the destination is the Land of hay-racks. For the private sector, it is important to ensure and monitor the quality. They have to implement additional tourist offers to keep tourist longer at the destination. The private sector must consider these challenges. Civil society is very important for the development of tourism. They supply additional activities, such as organizing events or information. These events are lacking in the Mirna Valley. Here are included tourist associations, cultural associations, the Association of Rural Women, choirs, wine clubs and sports associations. They are responsible for landscaping. Civil society is financed from the municipal budget.

During formation of the Regional Development Strategy the experts proposed some solutions that were put onto the time schedule. To a large extent, those solutions have not been realized. According to the findings, the area still has many opportunities for further developing and researching.

\section{References}

Aas, C., Ladkin, A., \& Fletcher, J. (2005). Stakeholder collaboration and heritage management. Annals of Tourism Research, 32(1), 28-48.

Ackermann, F., \& Eden, C. (2011). Strategic management of stakeholders: Theory and practice. Long Range Planning, 44(3), 179-196.

Aldehayyat, J. (2011). Organizational characteristics and the practice of strategic planning in Jordanian hotels. International Journal of Hospitality Management, 30(1), 192199.

Belak, J. (2002). Politika podjetja in strateški management: management in razvoj. Gubno: MER Eurocenter.

Blain, C., Levy, S. E., \& Ritchie, J. B. (2005). Destination branding: Insights and practices from destination management organizations. Journal of Travel Research, 43(4), $328-338$.

Bornhorst, T., Ritchie, J. B., \& Sheehan, L. (2010). Determinants of tourism success for DMOs \& destinations: An empirical examination of stakeholders' perspectives. Tourism Management, 31(5), 572-589.

Brownman, C. (1994). Bistvo strateškega managementa. Ljubljana, Slovenia: Gospodarski vestnik.

Dimovski, V. Panger, S. \& Žnidaršič, J. (2003). Sodobni management. Ljubljana, Slovenia: Ekonomska fakulteta.

Guiver, J. \& Stanford, D. (2014). Why destination visitor travel planning falls between the cracks. Journal of Destinational Marketing and Management, 3(3), 140151.

Haugland, S. A., Ness, H., Grønseth, B. O., \& Aarstad, J. (2011). Development of tourism destinations: An integrated multilevel perspective. Annals of Tourism Research, 38(1), 268-290.

Jamal, T. B., \& Getz, D. (1995). Collaboration theory and community tourism planning. Annals of Tourism Research, 22(1), 186-204.

Koščak, M. (2013). Strateško akcijski načrt za vzpostavitev turistične destinacije Mirnska dolina (Unpublished document). Studio MKA, Mokronog, Slovenia. 
Laesser, C., \& Beritelli, P. (2013). St. Gallen consensum on destination management. Journal of Destination Marketing and Management, 2(1), 46-49.

Mackey, D. \& Zundel, M. (2016). Recovering the divide: A review of strategic and tactics in business and management. International Journal of Management Reviews, 19(2), 175-194.

Magaš, D. (1997). Turistična destinacija. Opatija, Croatia: Hotelijerski fakultet.

Magaš, D. (2003). Management turističke organizacije i destinacije. Opatija, Croatia: Fakultet za turistićki i hotelski menadžment.

Munar, A. M. (2012). Social media strategies and destination management. Scandinavian Journal of Hospitality and Tourism, 12(2), 101-120.

Morgan, N. J., Pritchard, A., \& Piggott, R. (2003). Destination branding and the role of the stakeholders: The case of New Zealand. Journal of Vacation Marketing, 9(3), 285-299.

Mountinho, L., Ballantyne, R., \& Rate, S. (2011). The new business environment and trends in tourism. In L. Moutinho (Ed.), Strategic management in tourism (2nd ed., pp. 1-19). Cambridge, England: Cambridge University Press.

Okumus, F. \& Wong, K. F. (2005). In pursuit of contemporary content for courses on strategic management in tourism and hospitality schools. Hospitality Management, 24(2), 259-279.

Ovsenik, R. (2003). Perspektive in protislovja razvoja turističnega področja: model turističnega managementa na območju slovenskih Alp (Unpublished doctoral dissertation). Fakulteta za organizacijske vede, Kranj, Slovenia.

Presenza, A., Sheehan, L., \& Ritchie, J. B. (2005). Towards a model of the roles and activities of destination management organizations. Journal of Hospitality, Tourism and Leisure Science, 3(1), 1-16.

Pučko, D., Čater, T., \& Rejc Buhovac, A. (2009). Strateški management 2. Ljubljana, Slovenia: Ekonomska fakulteta.

Reid, D. (1996). Sustainable development: An introductory giude. London, England: Earthscan.
Ruhanen, L. (2010). Where's the strategy in tourism strategic planning? Implications for sustainable tourism destination planning. Journal of Travel and Tourism Research, $10(1 / 2), 58-76$.

Sautter, E. T., \& Leisen, B. (1999). Managing stakeholders a tourism planning model. Annals of Tourism Research, 26(2), 312-328.

Tavčar, M. (2008). Management in organizacija: celostno snovanje politike organizacije. Koper, Slovenia: Fakulteta za management.

Tavčar, M. (2002). Strateški management. Koper, Slovenia: Visoka šola za management.

United Nations World Tourism Organization. (2007). Practical guide to tourism destination management. Madrid, Spain: Author.

Uran, M. (2006). Strategija v turizmu. Portorož, Slovenia: Turistica.

Uran, M. (2014). Organiziranost slovenskega turizma. Retrieved from http://www.slovenia.info/pictures\% 5ccategory\%5catachments_1\%5C2014\%5corganiziranost _turizma_v_sloveniji_-_dr._maja_uran_18945.pptx

Volgger, M., \& Pechlaner, H. (2014). Requirements for destination management organizations in destination governance: Understanding D MO success. Tourism Management, 41, 64-75.

Waligo, V. M., Clarke, J., \& Hawkins, R. (2013). Implementing sustainable tourism: A multi-stakeholder involvement management framework. Tourism Management, 36, 342-353.

Wall, G., \& Mathieson, A. (2006). Tourism: Changes, impacts and opportunities. Harlow, England: Pearson Prentice Hall.

Whittington, R. (2001). What is strategy - and does it matter? London, England: Thomson Learning.

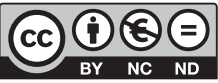

This paper is published under the terms of the Attribution- NonCommercial-NoDerivatives 4.0 International (CC B Y-NC-ND 4.0) License. 